\title{
The Quiet Revolution? The Labour Party and Welfare Conditionality
}

\author{
Dr Daniel Sage, Senior Lecturer in Social Sciences, Edge Hill University \\ daniel.sage@edgehill.ac.uk
}

\begin{abstract}
Labour's 2017 general election manifesto contained a pledge to 'end the punitive sanctions regime' in the British welfare state. Whilst the specific implications of this pledge were not elaborated, such a policy would nevertheless constitute a profound break with a welfare consensus spanning over twenty years. The depth of the suggested changes on welfare are also evident in the scale of reform proposed to disability benefits, as well as plans - confirmed in August 2018 by the Shadow Chancellor John McDonnell - to pilot universal basic income. Collectively, these policies would seemingly be deeply at odds with public opinion on the benefits system, which over the course of the last two decades has significantly hardened. Yet despite the seemingly radical and controversial nature of the policy, it received very little media or public attention during the election campaign. This article explores Labour's 'quiet revolution' on welfare, examining whether Labour's new welfare approach is indeed a bold attempt to reshape public opinion on welfare or, alternatively, a mostly pragmatic reaction to changing social attitudes. The argument presented is that whilst there are persuasive explanations that Labour is responding to a change in the public mood, there is also evidence of a more ambitious goal at stake: the aim of reshaping, not simply responding to, public opinion on the welfare state.
\end{abstract}

Keywords: public opinion; welfare conditionality; Labour Party; social attitudes; welfareto-work. 


\section{Introduction}

The June 2017 snap general election delivered a result that few predicted when the election was first called. From early opinion polls suggesting a 20 per cent lead for the Conservatives, the final vote gave Theresa May a victory of just 2.4 per cent and, now infamously, a hung parliament. The election saw Jeremy Corbyn lead Labour to a near 10 per cent rise in its vote share: from 30.4 per cent in 2015 to 40 per cent just two years later. For many people this was a remarkable result given the leftward shift and the pervading conventional wisdom that the Labour Party could not do well on a more leftwing platform. ${ }^{1}$

The Labour manifesto contained a range of more radical policies compared to recent general elections. These included the abolition of university tuition fees, water nationalisation and increased rates of income tax for higher earners. Social security proposals were similarly radical. Labour proposed abolishing some of the post-2010 welfare reforms, including the Spare Room Subsidy (the 'Bedroom Tax') and the removal of Housing Benefit for young people. Significant changes were also pledged to Universal Credit.

Most starkly however, the 2017 manifesto made multiple references to 'end the punitive sanctions regime' for benefit recipients. The specifics of the pledge were unclear, yet the message to the electorate was that Labour intended to roll back some of the conditionality introduced by the Conservative, Coalition and New Labour governments. In addition, Labour proposed radical changes to disability benefits (including a 'new sanctions regime' altogether) and has recently pledged to pilot universal basic income (UBI), an unconditional, universal guaranteed income. Amidst a glut of radical and purportedly controversial policies, the proposed reform of benefit sanctions have gone 
largely under the public and media radar. Yet ending, or even reforming, welfare sanctions would constitute a profound break with over two decades of UK social security policy.

With the Left of Labour now firmly placed in positions of power within the party, and post-election opinion polls showing continued high support for the party, it is an apt time to explore Labour's 'quiet revolution' on welfare. This article examines the policy and political context of welfare sanctions, with a particular emphasis on Labour's policy repositioning since 2017. The main question is whether this repositioning represents a genuine challenge to public opinion or, rather, a more pragmatic reaction to changing social attitudes on welfare. Whilst evidence is found for the latter, the article puts forward the argument that ultimately Labour is forging a new social policy approach compared to the recent decades: rather than following public opinion on welfare, it appears that Labour is attempting the purportedly more risky strategy of changing what people think. The article concludes however that transforming social attitudes to welfare might not be as risky as commonly perceived. For evidence that politicians can change public opinion on welfare quickly, dramatically and successfully, the contemporary Labour Party could look to an unlikely inspiration: New Labour in the late 1990s.

\section{The Politics of Conditionality}

Some degree of conditionality has long been part of the UK social security system, yet the present, more intensified, system can be dated to the Conservative reforms of the mid-1990s. These were initially targeted at unemployed people with the introduction of Jobseeker's Allowance and varying requirements and expectations on claimants to look for work and engage with job search support. The New Labour governments enthusiastically continued this trend, integrating conditionality firmly within its flagship 
welfare-to-work New Deal programmes. During the latter stages of the New Labour era, conditionality was controversially extended to other out-of-work groups, specifically lone parents and disabled people, although the application of sanctions was relatively rare compared to their use by the Conservative-led governments from 2010, who have enthusiastically continued and expanded the approach set out by New Labour (despite refrains from David Cameron that Labour were the 'party of unlimited welfare). The number of welfare sanctions issued expanded rapidly during the Coalition government and conditionality was extended further, including to those in paid employment under the new Universal Credit arrangements. The shift towards a highly conditional welfare state in the UK - within a broader a system of labour market 'activation' - is part of a global trend in advanced welfare states, albeit with varying levels and degrees of change.

New Labour had a central role in establishing conditionality as a cornerstone of the UK social security system, seeing it as a fundamental part of its Third Way between Thatcherism and post-war social democracy. Conditionality was based on the principle that benefit claimants would receive support from the state, in the form of services and benefits, but in return would be expected to search for and, if offered, accept paid work. This quid pro quo - of rights and responsibilities for both the state and the claimant - was one of the defining features of New Labour's political philosophy.

But just as with many other totems of the New Labour era, the current Labour leadership are threatening to discard conditionality. This can be seen in three recent developments. First, Labour's 2017 manifesto promised to 'end the punitive sanctions regime' in the benefits system. Whilst the particular policy implications of this pledge were unspecified, the broad conclusion must be that a future Labour government would bring about significant reform of conditionality for all affected claimants: including 
unemployed people, low-paid workers and lone parents. Second, Labour has been far clearer on the scale and detail of change proposed to disability benefits. Alongside its main manifesto in 2017, Labour published a separate manifesto outlining changes affecting disabled people. As well as raising benefits for certain groups of claimants, the disability manifesto pledged to scrap the Work Capability Assessment - the main tool used to determine eligibility to particular disability benefits - and introduce a new sanctions regime altogether. Third, over the past few years Labour has shown a strong interest in UBI: a universal benefit without any work requirements or means-testing. This culminated in August 2018 with the Shadow Chancellor, John McDonnell, pledging to include UBI pilots in the next Labour manifesto. ${ }^{2}$ These proposals give a sense of how a future Labour government would change welfare conditionality. Least radically, we could expect significant changes to disability benefits, including the existing sanctions regime. Most radically however, the entire existing social security system could be replaced by an unconditional, universal benefit: UBI. Either way, even the less radical option would mark a significant shift in welfare policy.

This approach does not just represent a break between Jeremy Corbyn's Labour Party and the New Labour governments of Blair and Brown but between Corbyn and his predecessor Ed Miliband. Whilst parts of the British media warned of 'Red Ed' and the purported threat of socialism ${ }^{3}$, the more mundane reality was that many of Miliband's policies could be interpreted as quite modest social democratic reforms. Nowhere was this modesty more revealing than in Miliband's approach to welfare reform. Cautious of apparently tough pubic attitudes on benefit recipients, the 2015 Labour manifesto was careful to qualify its offer of a guaranteed job to every young unemployed person with the caveat that if they failed to accept it they would lose benefits. In this sense 
Miliband's Labour - for all the media scaremongering around a shift to the Left - fell squarely within the rights and responsibilities tradition of Blair and Brown.

\section{Understanding Labour's Welfare Strategy}

Labour's recent policy on welfare conditionality thus represents a break with a political consensus that spans a quarter of a century and which has been embraced by a variety of ideological factions within both Labour and the Conservatives. However, what makes Labour's challenge to conditionality all the more remarkable is that it seemingly breaks with another political tradition of the past two decades: the instinct that politicians must follow public opinion rather than try and reshape it.

This was a key explanation for trying to understand the pace and enthusiasm with which welfare reforms were implemented over the past ten years: rapid, tough change for benefit claimants is what much of the public wanted to see. Public attitudes to the welfare state, and in particular unemployed people, have hardened since the end of the 1990s and throughout the 2000s and early 2010s. Between 1994 and 2011, the percentage of British Social Attitudes (BSA) respondents who stated that unemployment benefits were 'too high and discourage (unemployed people) from finding jobs' increased from 24.9 per cent to 64.1 per cent. Labour's historic association with the welfare state, despite the reforms of the 2000s, was also used to explain the scale of its 2015 election defeat. Such was the hostility of the public to the benefits system, Margaret Beckett's report into the 2015 election argued that one of the reasons Labour lost so heavily was because it was identified as the 'party of welfare'. With this in mind, Labour's recent shift against the welfare consensus of the past two decades looks all the more bold, as well as all the more at odds with recent, popular approaches to responding to public opinion. 
There are question marks however over the extent to which Labour's new approach really is at odds with dominant social attitudes or, alternatively, whether its new welfare policy is actually in tune with changing public opinion. In this latter regard, there are three arguments that stand out. The first is that other issues have overtaken social security and unemployment as issues of public concern. Evidence for this comes from IPSOS Mori's long-running Issues Index, which asks respondents to identify what they consider to be the most important issues facing the country. Figure 1 shows how unemployment was judged by many to be a key issue between 2011-2013, when around a third of people highlighted it as one of the most important issues facing Britain. However as the labour market has improved since 2013, the perceived importance of unemployment has fallen significantly. Simultaneously other issues, most notably the EU and the NHS, as well as to a lesser extent poverty, have become much more salient in the public mind. Whilst it is unclear that public concern with unemployment causes tougher attitudes towards benefit claimants, the high point of concern with unemployment (20112013) did coincide with the high point of public concern with benefit claimants. Additionally, the public appear more worried about issues Labour is traditionally seen as stronger on, such as poverty and healthcare. The increased concern with issues Labour is more trusted on, together with the reduced concern with issues it is less trusted on, may have created the space for Labour to be bolder on welfare reform.

Figure 1 here

A second argument for understanding Labour's new welfare approach is that public attitudes to welfare have never been as tough, uncompromising and homogeneous as many politicians and academics have thought. This is argued by Geiger and Meuleman ${ }^{4}$, who contend that whilst welfare attitudes have certainly hardened over the past twenty 
years, most people's views about social security are at root ambivalent: people tend to have both concerns about the welfare state whilst simultaneously feeling that it has some largely positive functions. Labour's strategy can in part be seen in this light. Much of Labour's rhetoric on welfare has focused on groups that people are more likely to associate as 'deserving' and, as such, where the public are more likely to find the impact of welfare reform to be objectionable. This includes the experiences of many disabled people with new disability assessment procedures, as well as the reliance on food banks amongst many of the in-work poor.

The third argument for Labour's new welfare strategy is that the party is not in fact boldly opposing dominant public opinion but is rather responding to changes in social attitudes. One of the most recent BSA reports for example shows that there has been a rapid fall in perceptions of benefit fraud and manipulation. ${ }^{5}$ In addition, people are less likely to support further cuts to social security benefits than they were a few years ago. In 2010, 42 per cent of BSA respondents said that cutting benefits 'would damage too many people's lives'; by 2017 this had risen to 56 per cent.

The gap between what Labour and Conservative supporters think about the welfare state has also been widening in recent years. This suggests that whilst Labour's welfare policy may look radical from the outside, it is quite in tune and probably well received by those who identify with the party. The belief, for example, that benefits are too low rose from 9.8 per cent to 14 per cent between 2011 and 2016 amongst those identifying with the Conservative Party. As such, the Conservatives also appear to be responding to the softening of welfare attitudes amongst their supporters, pledging 'no plans for further radical welfare reform' in their 2017 election manifesto. For Labour identifiers however, the corresponding increase was from 26.5 per cent to 44.5 per cent. Views on benefits 
thus appear to be softening across the political spectrum yet at a much faster pace for those identifying with Labour.

\section{Reshaping or Following Public Opinion?}

So how can Labour's new welfare approach, as well as the lack of media or public reaction, be explained? After all, since the 2017 general election Labour has put forward a policy approach that was widely attributed to the catastrophic election defeat in 2015. The above discussion suggests Labour's apparently radical approach may not be as out of tune with public opinion as it initially seems. On the one hand, public attitudes have softened towards welfare and benefit recipients. This is true of attitudes towards benefit spending and is particularly the case for specific groups of claimants, such as disabled people. It may also be true that social attitudes to welfare were never as toxic as conventionally thought. Whilst people are critical of the welfare state they are also able to see the good it does, with Labour tapping into these positive associations and avoiding more critical ones. To this we can add the recent public salience of issues like Brexit and the NHS. Voters are less likely to pay attention to welfare and unemployment than they were five years ago. For these reasons it is arguable that Labour is not so much confronting as following changing public opinion.

It is important however to keep public opinion on welfare in perspective. As Table 2 shows, large numbers of people continue to hold hostile views on benefit claimants and, in particular, unemployed people. Whilst overall views on welfare may be softening, especially for particular groups of claimants like disabled people, it remains true that many people think benefits are too high, that they discourage work and that in fact most people who do not have a job could find one if they really wanted to. Although several years old, the 2012 BSA survey also demonstrates strong support for the principle of 
welfare conditionality. A remarkable 85.5 per cent of respondents were in favour of requiring unemployed people to carry out unpaid community work in return for benefits. In addition, recent research suggests that there is sizeable support for conditionality being applied to in-work benefit recipients too. ${ }^{6}$ Removing conditionality altogether, or even diluting it, would still constitute a significant challenge to what many people tend to think about the welfare state.

Table 2 bere

Evidence from the BSA series thus shows large numbers of people continuing to hold critical and hostile views on welfare whilst there appears to be extremely strong support for the principles of conditionality and sanctioning. There is consequently a fourth way of understanding Labour's new welfare strategy. This is that Labour is attempting to do what has long been considered on the Left to be both improbable and undesirable: to transform public attitudes on welfare. As Geiger and Meuleman note, the most common approach on the Left in recent years has been to argue for accepting public opinion on welfare and working with social attitudes, not against them. This explains Ed Miliband's strategy of offering more support to benefit claimants than the Conservatives would (via a job guarantee) but ensuring this support is strictly qualified by conditionality and the threat of benefit sanctions. Unlike Miliband, it would appear that Corbyn's Labour believes public opinion on welfare can be decisively shifted after all.

Transforming public opinion on key policy areas appears an obvious goal for political parties. Yet in reality this constitutes a dramatic change in how British politicians have understood and reacted to social attitudes in recent years. Since New Labour at least, there has been a tacit assumption that politicians should follow public opinion rather 
than try and reshape it: that social attitudes are social facts that are entrenched and must be accommodated. This was exceptionally clear in 2015 shortly after Labour's general election defeat. Such was the concern with the supposed incongruity between Labour and the public on welfare that the interim leader, Harriet Harman, led the party to abstain on the Conservatives' welfare bill, which included controversial plans to limit tax credits to two children. Labour's policy on welfare has, like most other policy areas, shifted decisively to the Left under the new leadership. However whilst Labour has developed more left-wing policies in most policy areas in most since 2015, many of these chime with public opinion. These include relatively popular left-wing policies on transport and utilities nationalisation, as well as increased spending on public services. It seems that welfare is unique in the sense that Labour has moved considerably to the Left whilst the public has not.

The capacity of political parties however to reshape public opinion may be more straightforward and attainable than politicians have commonly thought. Indeed, in emphasising so strongly the responsibilities of benefit claimants to find and accept paid work, New Labour itself was hugely successful - albeit perhaps inadvertently - in bringing about a major change in welfare attitudes. Prior to 1997, public opinion on welfare was relatively benign. In the mid-1990s, evidence from the BSA series suggested a widespread sympathy with unemployed people. There was support for the distribution of benefits to those in need, a weak tendency to blame joblessness on the unemployed themselves and a belief that government should provide a decent standard of living to benefit recipients. $^{7}$ Such was the public backing of the welfare state that Taylor-Gooby declared in 1994 that 'the foundations of public support for the welfare state had never been more solid'. ${ }^{8}$ 
By the early 2000s, the public environment had changed to one much more hostile to the welfare state. As documented above, people were now much more likely to think benefits were too high and that most people could find a job if they really wanted one. Public support for less spending on the unemployed also rocketed in the mid-2000s. Part of this shift can be explained by the economic cycle: the tendency for welfare attitudes to harden in times of economic growth and high employment levels. However, tough welfare attitudes persisted in the immediate post-crisis years when unemployment was rising. Additionally, there is evidence to suggest that young people have transformed from a broadly pro-welfare group to one that is anti-welfare ${ }^{9}$ and that the biggest change in welfare attitudes occurred amongst Labour Party supporters. ${ }^{10}$ All three of these points are evidence of a more fundamental shift in public opinion in the 2000s, tied to the increased use of welfare conditionality and the persistent emphasis on the behaviour and responsibility of benefit claimants.

Although the parallel focus on the responsibility of the state to provide more support for out-of-work groups was intended to temper the emphasis on the responsibilities of the unemployed, the end result was nevertheless a conservative recasting of the public imagination on welfare. New Labour's policy focus on conditionality was firmly linked with a profound transformation in how unemployment, and social security more broadly, was viewed. O'Grady demonstrates the link between New Labour's rhetoric and changing public attitudes by showing how the qualitative nature of political speeches about welfare in the House of Commons has changed since the 1980 s. ${ }^{11}$ O'Grady shows that in Labour Party speeches, negative depictions of welfare overtook positive depictions of welfare before the shift in public opinion occurred; New Labour did not respond to changing social attitudes but actively reshaped them. Over time however, New Labour wrongly diagnosed the provenance of hostile welfare attitudes. Labour 
assumed that such attitudes were independent of the actions and rhetoric of political parties and, in believing this, became terrified to confront a monster of its own making.

The experience of New Labour thus provides convincing evidence that political parties can, after all, reshape public opinion: a conclusion that should give confidence to the present project of redirecting attitudes in a decidedly more left-wing orientation. In the most radical manifestation of the confidence that it can change public opinion on welfare, Labour has recently demonstrated an interest in UBI an unconditional, regular payment to all citizens. In early 2017, the Shadow Chancellor John McDonnell established a working group to explore the feasibility of UBI and in the summer of 2018 McDonnell announced Labour's plans to include a UBI pilot in its next manifesto. If Labour were to propose a UBI-type scheme, then this would truly test the malleability of public opinion on welfare for three key reasons. First, a UBI would require governments to identify significant additional income and, consequently, build public support for higher taxes. Second, UBI would have to address the social norms around welfare provision detailed in this article, specifically the importance many citizens place on notions of desert, contribution, need and reciprocity: principles at odds with those that underpin UBI. Third, UBI would also need to engage with debates around the importance of paid work and the centrality of employment and the work ethic to many voters. Whilst there are strong arguments that UBI incentivises paid work, there are parallel arguments that UBI will liberate people from the necessity of employment altogether. Gaining public support for UBI is not impossible but would require a profound shift within these three aspects of public opinion.

\section{Conclusion}


The Labour Party under Jeremy Corbyn has adopted a welfare approach - ending the 'punitive sanctions regime', disability benefit reform and interest in UBI - that seems strongly at odds with public opinion on social security. Yet despite this, these policies received little public attention in the 2017 general election. This article has explored the rationale behind this new welfare approach and identified a range of reasons for both its inclusion in the manifesto and the lack of attention it has received. Whilst public opinion on welfare appears to be shifting, and attitudes may have never been as toxic as commonly assumed, it appears that Labour is thinking the purportedly unthinkable: that public attitudes on welfare can be transformed by political parties. Whilst this has until recently represented an unpopular view amongst left-wing politicians, the consequences of New Labour's own welfare approach in the late 1990s should give justification and confidence to this new welfare project. Perhaps inadvertently, New Labour's policy and rhetoric on welfare was effective in profoundly shifting public opinion towards a much more critical and hostile perspective on welfare. Whether Jeremy Corbyn's Labour Party can achieve something similar, but in the alternative direction, remains to be seen. 
Figure 1. IPSOS Mori Issues Index, 2007-2017

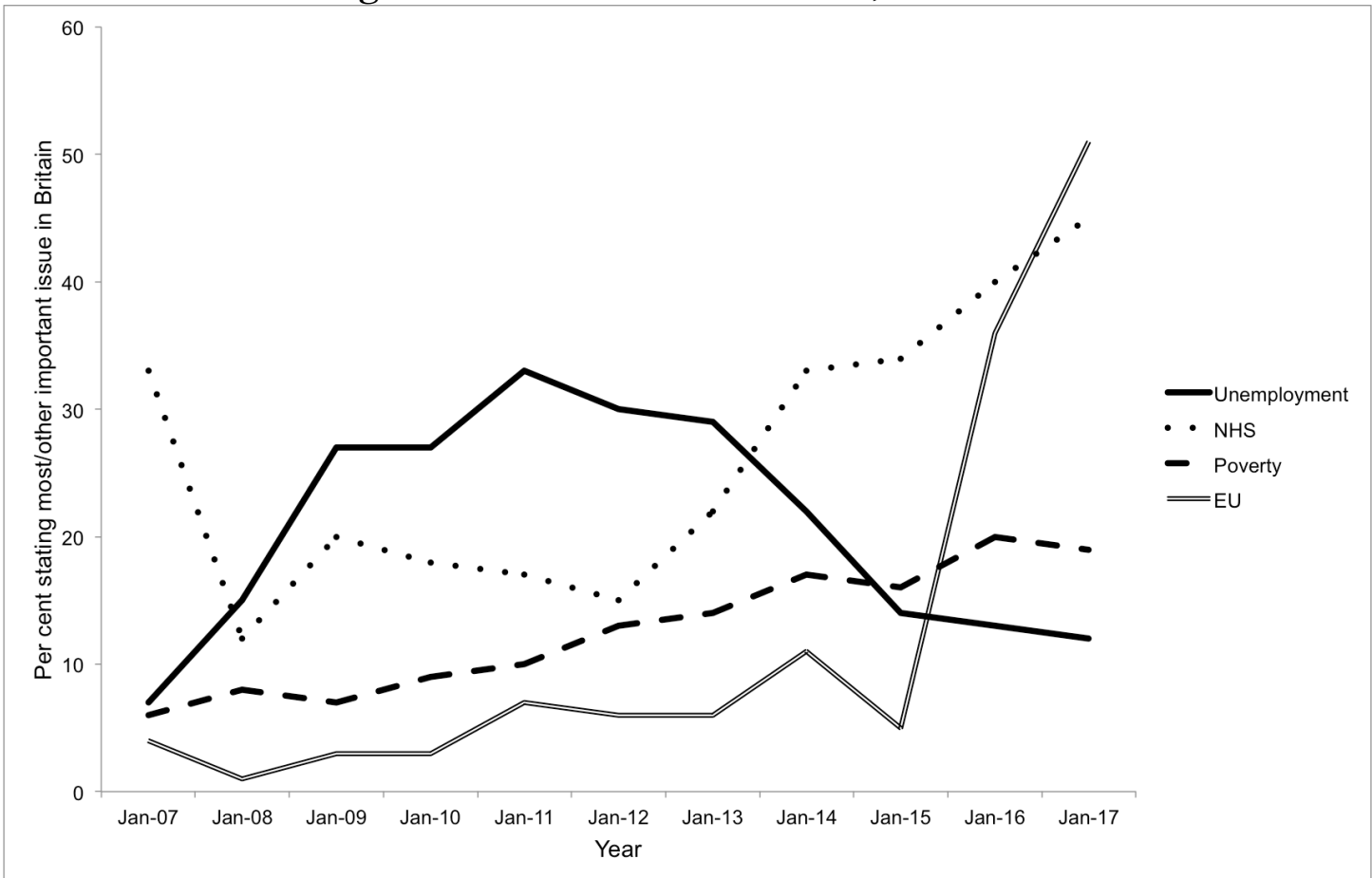

Table 2. Attitudes to Unemployment and Benefits, British Social Attitudes 2016

\begin{tabular}{|l|l|}
\hline BSA Question & $\begin{array}{l}\text { Per cent } \\
\text { agreeing/agreeing } \\
\text { strongly with } \\
\text { statement }\end{array}$ \\
\hline $\begin{array}{l}\text { Unemployment benefits are too high and discourage people from } \\
\text { working }\end{array}$ & 49.2 \\
\hline $\begin{array}{l}\text { If welfare benefits weren't so generous people would learn to stand } \\
\text { on their own two feet }\end{array}$ & 44.2 \\
\hline $\begin{array}{l}\text { Around here, most unemployed people could find a job if they really } \\
\text { wanted one }\end{array}$ & 57.1 \\
\hline $\begin{array}{l}\text { It is probably/definitely not the government's responsibility to } \\
\text { provide a decent standard of living for the unemployed }\end{array}$ & 39.8 \\
\hline
\end{tabular}


${ }^{1}$ BBC, Tony Blair Warns Against Moving Left as Jeremy Corbyn Leads Polls, BBC News, accessed $15^{\text {th }}$ May 2018, available online: http://www.bbc.co.uk/news/uk-politics-33619645

2 Cowburn, A. (2018), Labour Set to Include Pilot of Radical Basic Income Policy in Next Manifesto, John McDonnell Says, The Independent, 31 st July 2018, available online: https://www.independent.co.uk/news/uk/politics/labour-universal-basic-income-john-mcdonnell-partymanifesto-corbyn-poverty-social-benefits-a8471616.html

${ }^{3}$ Gaber, I. (2015), The 'Othering' of 'Red Ed', or how the Daily Mail 'Framed' the British Labour Leader, The Political Quarterly, 85(4): 471-479.

4 Geiger, B.B. and Meuleman, B. (2016), Beyond 'Mythbusting': How to Respond to Myths and Perceived Undeservingness in the British Benefits System, Journal of Poverty and Social Justice, 24(3): 291-306.

${ }^{5}$ Geiger, B.B., Reeves, A. and De Vries, R. (2017), Tax Avoidance and Benefit Manipulation: Views on its Morality and Prevalence, in Clery, E., Curtice, J. and Harding, R. (eds.), British Social Attitudes 34, London: NatCen.

${ }^{6}$ Abbas, J. (2017), Working Hard or Hardly Working? Universal Credit and the Problem of Conditionality, IPR Blog, 20 th October 2017, available online: https://blogs.bath.ac.uk/iprblog/2017/10/20/workinghard-or-hardly-working-universal-credit-and-the-problem-of-conditionality/

7 Sage, D. (2012), Fair Conditions and Fair Consequences? Exploring New Labour, Welfare Contractualism and Social Attitudes, Social Policy and Society, 11(3): 359-373.

${ }^{8}$ Taylor-Gooby, P. (1994), Comfortable, Marginal and Excluded: Who Should Pay Higher Taxes for a Better Welfare State?, in Jowell, R., Curtice, J., Park, A., Brook, L. and Ahrendt, D. (eds.), British Social Attitudes: The $12^{\text {th }}$ Report, Aldershot: Dartmouth Publishing Company. 
9 Deeming, C. and Johnston, R. (2018), Coming Together in a Rightward Direction: Post-1980s Changing Attitudes to the British Welfare State, Quality and Quantity, 52: 395-413.

${ }^{10}$ Hills, J. (2002), Following or Leading Public Opinion? Social Security Policy and Public Attitudes Since 1997, Fiscal Studies, 23(4): 539-558

11 O’Grady, T. (2017), How Politicians Created, Rather Than Reacted To, Negative Public Opinion on Benefits, LSE British Politics and Policy, $7^{\text {th }}$ November 2018, available online: http://blogs.lse.ac.uk/politicsandpolicy/public-opinion-towards-welfare/ 